\title{
Impact Assessment From Coal Mining Area in Southern Brazil
}

\author{
Monique B. Schlickmann ${ }^{1}$, Jaqueline B. B. Dreyer ${ }^{1}$, Fabio R. Spiazzi ${ }^{1}$, Francielle S. Vieira ${ }^{1}$, Bruno Nascimento ${ }^{1}$, \\ Edilane R. Nicoleite ${ }^{2}$, Maria R. Kanieski ${ }^{1}$, Edilaine Duarte ${ }^{3}$, Chaiane R. Schneider ${ }^{3}$ \& Jéssica T. de Aguiar ${ }^{4}$ \\ ${ }^{1}$ Departament of Forest Engineering, Santa Catarina State University, Lages, Brazil \\ ${ }^{2}$ Biosciences Institute, Federal University of Rio Grande do Sul, Porto Alegre, Brazil \\ ${ }^{3}$ Departament of Agricultural Sciences, Federal University of Parana, Curitiba, Brazil \\ ${ }^{4}$ Departament of Forest Engineering, Midwestern State University, Irati, Brazil \\ Correspondence: Monique B. Schlickmann, Departament of Forest Engineering, Santa Catarina State University, \\ Lages, SC 97105-900, Brazil. Tel: 55-48-9651-7895. E-mail: moniqueschlickmann@gmail.com
}

Received: April 11, 2018

doi:10.5539/jas.v10n8p426
Accepted: May 22, $2018 \quad$ Online Published: July 15, 2018

URL: https://doi.org/10.5539/jas.v10n8p426

\begin{abstract}
The mining activity is highly environmental impacting, being the excavation process and waste sterile rejects crowding the main pollution sources. The Santa Catarina Coal Basin has great importance, considering that contains 4.3 billions tons of coal (13\% of the Brazilian reserve) and 6.400 hectares of degraded area. That way, the study objective was to characterize and identify the ambient impacts derivated from coal mining activities, at the Sideropolis city, SC. The base method used to evaluate was The Leopold matrix which adaptations were made according to a qualitative attribute weighting matrix to verify the significance of impacts. The interaction between two actions of the enterprise and 11 generated environmental impacts was analysed according to the attributes of frequency, extension, duration, direction and degree, both in the physical and anthropic environments. All impacts had a negative direction, where the most striking activity was the opening of the cava, which, when forming the acidic lagoon, changes the surface water quality, being described as of great importance. Therefore, recognizing the principal environment problems could help on strategies to accomplish the recovery requirements of degraded areas on this area.
\end{abstract}

Keywords: environmental resources, extraction, mineral coal

\section{Introduction}

A new interest has recently emerged worldwide in the reduction of nuclear energy usage, mainly due to the Fukushima disaster, which occurred in Japan in 2011 (Costanza et al., 2011). In fact, the new interests were directed to coal mining, which is an activity that grew globally, mainly in South Africa, China, Australia and India (Larondelle \& Haase, 2012), which are the countries that produce most of this mineral. In short, coal provides $29.6 \%$ of global energy needs and about $42 \%$ of all world electricity, increasing its consumption by 46\% from 2001 to 2010 (World Coal Association, 2011).

So much exploitation in a certain natural resource, consequently would occur in relevant environmental problems. Open pit coal mining is one of the activities that most modify the natural landscape, resulting in almost always irreversible conditions (Slonecker \& Benger, 2001). In this case, it is important to note that there is a strong correlation between the physical and chemical properties of the soil (Fugaro et al., 2006). This modification occurs mainly by the presence of sulfuric mineral waste (e.g. pyrite and marcassite) that oxidize in the presence of air, water and action of the bacterium Thiobacilus ferroxidans triggering an acidification process (Fugaro et al., 2006). This process ends up committing a great part of the water resources and the surrounding (Soares et al., 2006; Pompêo et al., 2004).

According to Macêdo et al. (2001), mining can be still carried out in the open or underground, based mainly on economic criteria. According to the author, the open pit method results in greater environmental impacts, due to the greater volume of material handled. In addition, to being carried out in the open, in the process of beneficiation, in the separation of coal from other aggregate materials such as pyrite, siltstones and shales, there is generation of environmental pollution due to the deposition of the tailings (Gonçalves \& Mendonça, 2007). For open pit mining, it is necessary to remove the vegetation cover and to perform the excavation operation, 
which generates a large amount of sterile material and, deposited near the mining sites in piles or dams, generating depreciation of land and contamination of the surroundings of these mining enterprises (Spiazzi et al., 2009; Campos et al., 2010).

In this sense, any activity that causes the alteration of the physical, chemical or biological properties of the environment and directly or indirectly affects the health, safety, social and economic activities, aesthetic and sanitary conditions of the environment are considered an environmental impact (Brasil, 1986). This concept results from an environmental aspect (processes or mechanisms that generate consequences) and, although it is largely related to a negative perspective, it also applies to positive changes. However, environmental degradation corresponds to negative environmental impact, being any adverse change in environmental quality (Sánchez, 2012).

In fact, the environmental impacts of coal mining activities are a problem in Santa Catarina, southern Brazil, where mining activities occurred mainly from 1940 to 2000 (Citadini-Zanette, 1999). This is one of the brazilian areas that have an important environmental degradation, classified as XIV National Critical Area in terms of environmental pollution (Brazil, 1980). At the end of the mining activity, about 6.500 hectares were abandoned, with no attention being paid to environmental and social changes (Rocha-Nicoleite et al., 2013; Rocha-Nicoleite, 2015; Rocha-Nicoleite, 2017). Similar situations have occurred in other mining areas around the world (Bell et al., 2001; Johnson, 2001; Cravotta, 2008; Mishra et al., 2012; Gutiérrez et al., 2016; Kim et al., 2016; Venkateswarlu et al., 2016; Bailey \& Hooey, 2017; Merem et al., 2017).

There are a large number of mines in the world that have not been properly closed without the restoration of the environment (Fields, 2003; Pepper et al., 2014; McHaina, 2001; Kubit et al., 2015; Cueva, 2017; Keeling \& Sandlos, 2017). Thus, although not functioning, these sites continue to promote the degradation of surrounding lands and water bodies (Gutiérrez et al., 2016; Kim et al., 2016; Venkateswarlu et al., 2016). In short, it is necessary to carry out projects aimed at the restoration of these sites, making these areas with stable conditions, mainly with the purpose of guaranteeing public safety (Schmidt \& Glaesser, 1998; Heorkin \& Sheoran, 2010; Limbrela \& Briel, 2014; Mborah et al., 2015; Lima et al., 2016). However, for this to happen, initially the areas degraded by mining must undergo an environmental assessment, which will later allow the creation of projects that can minimize negative impacts and allow the use of land for other purposes.

Based on the foregoing, and aiming at the lack of studies in the Carboniferous Basin of Santa Catarina, this work had as objective to provide elements and information on the environmental impacts of the activities of mechanical excavation and deposition of tailings/barren from the beneficiation of coal in this area. It was hypothesized that the impacts caused by the excavation and deposit of tailings in the study area, which occurred from 1940 to 2000, would be causing negative damages in the physical and anthropic environment until the present years (2018) even though it was inoperative and abandoned. In this sense, the results found may provide subsidies for future environmental restoration and conservation projects in the study area.

\section{Method}

\subsection{Study Area}

The study was carried out in a degraded area of tailings deposit and coal pit, in the municipality of Siderópolis, located between the coordinates $28^{\circ} 3^{\prime} 32.33^{\prime \prime} \mathrm{S}$ and $49^{\circ} 27^{\prime} 28.29^{\prime \prime} \mathrm{W}$ (Figure 1). The Municipality has $262 \mathrm{~km}^{2}$ of total area and 13,590 inhabitants, along with nine other municipalities that compose the Association of Municipalities of the Carboniferous Region (AMREC). The area is located in the Paraná Basin, at the top of the Rio Bonito and Palermo formations, located in the Carbonífera Catarinense Basin that extends for a range of 20 $\mathrm{km}$ in the East-West direction for $70 \mathrm{~km}$ in the north-south direction in the state of Santa Catarina, Brazil (Brazil, 1987).

The area impacted by the study was exploited for about 40 years (1945/8-1980) and currently corresponds to a forest fragment of 43.5 ha (Figure 1), in which from the activity of the open pit and the abandonment of the mined area produces an artificial lagoon of approximately 3.0 ha. According to the classification of Köppen, the climate in the region is Wet Temperate (Cfa) (Alvares et al., 2013). 


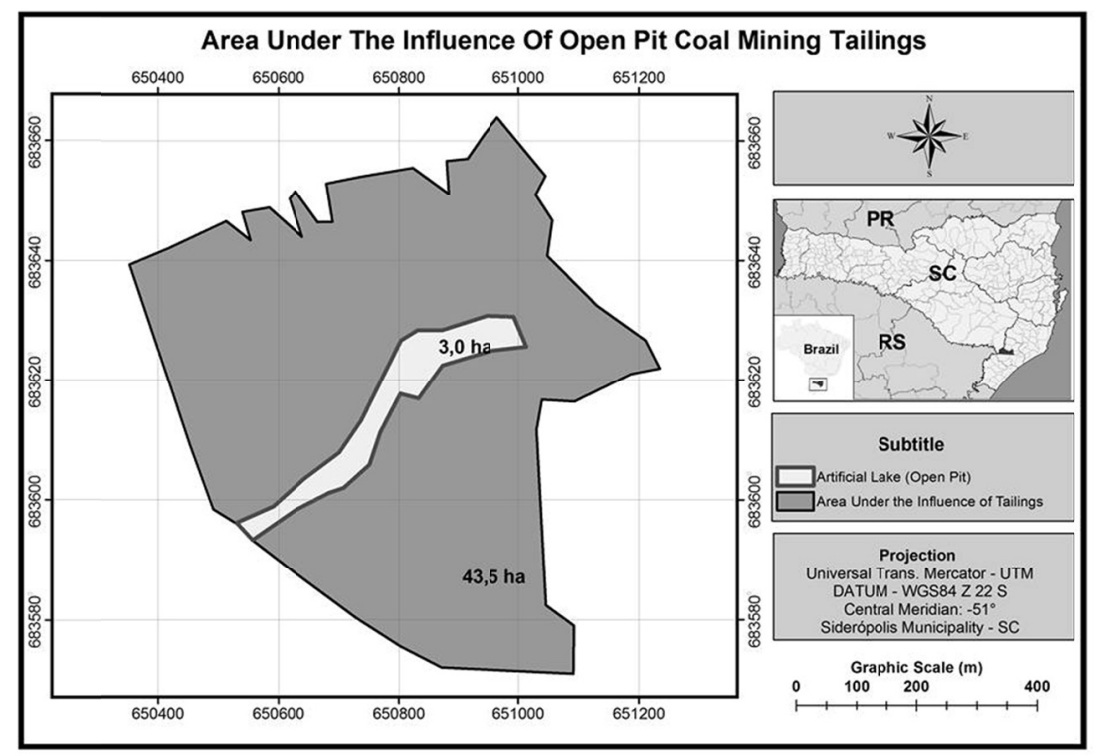

Figure 1. Area under influence of open coal mining activities in Siderópolis, Santa Catarina, Brazil

In the area there is a pile deposition of the wastes and barren (Figure 2A) and an artificial lagoon (Figure 2B) formed by the outcropping of the water table caused by the main mining pit.

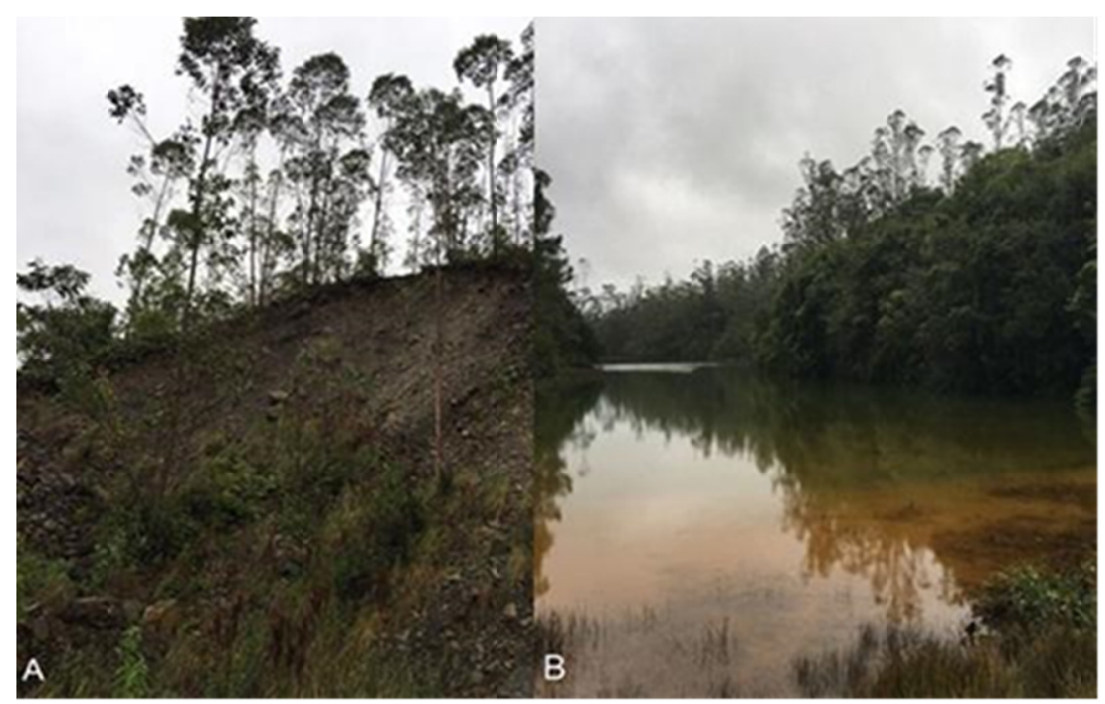

Figure 2. Areas impacted by mining activities. A) Sterilized deposition area. B) Acid lagoon formed with the open pit

\subsection{Data Collection and Analysis}

The data was collected through the observations of the affected areas and also based on reports that showed the history of the study area, where it was possible to diagnose a situation of the place. It was used to identify and describe the possible recurrent environmental impacts of tailings deposit activities and excavate the Leopold matrix (Leopold et al., 1971). Leopold's matrix was created in 1971 by the geologist Luna B. Leopold and her colleagues in response to the United States Environmental Policy Act of 1969, in which it did not clearly instruct the preparation of environmental impact reports (Josimovic et al., 2014). In this sense, a Leopold matrix provides a weighted analysis of environmental impacts relating to impacting activities (Leopold et al., 1971). Thus, it is possible to base this matrix/table, which is how the project activities are being modified in the environment they are inserted (Morris \& Therivel, 1995). 
The study analyzed the activities related to the stages of operation and subsequent to this, identifying the actions/activities generating and the possible environmental impacts. This cause and effect relationship aims to identify and establish connections (Sánchez, 2013). Adaptations were made in the matrix, in order to insert impacts from the mining, and to evaluate qualitatively the importance of the observed impacts from the evaluated parameters, following the criteria of Santos (2004), Sobral et al. (2007) and Costa (2016):

$>$ Frequency: (T) Temporary, when the effect is manifested for a period of time, (PR) Permanent, when it is found that the effect cannot be reversed and (C) Cyclic when the effect is seen from time to time;

$>$ Extension: (L) Local, where the effect occurs only at the degraded site and (RG) Regional, when it exceeds the affected site;

$>$ Duration: (ST) Short Term, when the effects can last up to one year, (MT) Medium Term, duration from one to ten years and (LT) Long Term, lasting from ten to fifty years;

> Direction: $(\mathrm{N})$ if the impact has a Negative direction or $(\mathrm{P})$ the impact can have a Positive direction;

$>$ Degree of impact: (L) Low, when using natural resources in negligible quantities, (A) Average, when using natural resources in significant quantities, but not to the point of exhaustion and $(\mathrm{H}) \mathrm{High}$, when the action can cause scarcity of natural resources.

The quantification of each impact, we applied the values from 1 to 3 in order to obtain a sum with the most importance impacts, being $1=$ low; $2=$ medium; $3=$ High $($ Table 1 ).

Table 1. Weights assigned to the attribute scale of a given impact for ponderation

\begin{tabular}{|c|c|c|c|c|}
\hline Attribute & Weight & Scale & Assigned value & Weighted value $(P \times V a)$ \\
\hline \multirow[t]{3}{*}{ Frequency } & 3 & Temporary & 1 & 3 \\
\hline & & Cyclic & 2 & 6 \\
\hline & & Permanent & 3 & 9 \\
\hline \multirow[t]{2}{*}{ Extension } & 2 & Local & 1 & 2 \\
\hline & & Regional & 2 & 4 \\
\hline \multirow[t]{3}{*}{ Duration } & 3 & Short term & 1 & 3 \\
\hline & & Medium term & 2 & 6 \\
\hline & & Long term & 3 & 9 \\
\hline \multirow[t]{2}{*}{ Direction } & 5 & Positive & 1 & 5 \\
\hline & & Negative & 2 & 10 \\
\hline \multirow[t]{3}{*}{ Degree of impact } & 5 & Low & 1 & 5 \\
\hline & & Average & 2 & 10 \\
\hline & & High & 3 & 15 \\
\hline
\end{tabular}

In order to classify the importance of each environmental impact, the assigned values of each scale/characteristic was weighted with the weight of the evaluated attribute, as shown in the table 2 . In order to assess the degree of importance of each environmental impact, were added all the results referring to the multiplication of the attribute with the scale value/characteristics evaluated, obtaining the total score. Thus, the degree of importance can be classified into: Small importance, when the lower limit is equal to or greater than 25 and less than or equal to 30; Average importance, when the value is equal to or greater than 31 and less than or equal to 36; Great importance, when the lowest value is equal to or greater than 37 and less than or equal to 42 .

Table 2. Degree classification due to importance of the environmental impacts

\begin{tabular}{lll}
\hline Importance & Inferior limit & Superior limit \\
\hline Small (S) & 25 & 30 \\
Average (A) & 31 & 36 \\
Great (G) & 37 & 42 \\
\hline
\end{tabular}

\section{Results}

From the characterization of the coal mining process, carried out through observations and with the help of local technical reports, activities potentially impacting the physical and anthropic environment were evidenced. The 
matrix was composed of two activities (columns) and 11 possible impacts (lines), according to frequency, extension, duration, direction and degree of impact, resulting in a total of 286 interactions. Table 3 presents a general picture of the aspects and impacts of the process of exploration and treatment of coal at the site under study.

Table 3. Environmental aspects and impacts of mining

\begin{tabular}{lll}
\hline Activities & Aspects & Impacts \\
\hline Pit opening & Increased sediment load on water bodies & Deterioration of surface water quality \\
& Formation of the artificial lagoon & Loss of terrestrial habitats \\
& Water table exposure & Creation of new environments \\
& Generation of wastes/barren & Landscape change \\
\hdashline Dispersion of gases and dust & Deterioration of air quality \\
& Soil deconstructed & Deterioration of soil quality \\
& Altering the local topography & Visual impact \\
\hline
\end{tabular}

Source: Adapted from Sánchez (2012).

Based on the results found by the matrix (Figure 3), it was possible to clearly identify how harmful the activities are to the environment, based on their characteristics and importance values. When mining takes place in the open, the excavation of large volumes of soil and the generation of considerable volumes of barren generate at first a great visual impact.

\begin{tabular}{|c|c|c|c|c|c|c|c|c|c|c|c|c|c|c|c|c|c|}
\hline \multirow{2}{*}{\multicolumn{2}{|c|}{$\begin{array}{l}\text { Imapcting } \\
\text { Activities }\end{array}$}} & \multirow{3}{*}{ Enviromental Impacts } & \multicolumn{13}{|c|}{ Characteristics } & \multirow{4}{*}{ Punctuation } & \multirow{4}{*}{$\begin{array}{r}\text { Degree of } \\
\text { importance }\end{array}$} \\
\hline & & & \multicolumn{3}{|c|}{ Frequency } & \multicolumn{2}{|c|}{ Extension } & \multicolumn{3}{|c|}{ Duration } & \multicolumn{2}{|c|}{ Direction } & \multicolumn{3}{|c|}{ Degree of Impact } & & \\
\hline $\begin{array}{c}\text { Tailings } \\
\text { Deposition }\end{array}$ & Pit & & $\mathbf{T}$ & PR & $\mathbf{C}$ & $\mathbf{L}$ & $\mathbf{R}$ & ST & MT & LT & $\mathbf{P}$ & $\mathbf{N}$ & $\mathbf{L}$ & $\mathbf{A}$ & $\mathbf{H}$ & & \\
\hline & & & \multicolumn{13}{|c|}{ Physical Environment } & & \\
\hline \multirow[t]{2}{*}{$\mathbf{X}$} & & \multirow{2}{*}{ Change in soil characteristics } & & $3 * 3$ & & $1 * 2$ & & & & $3 * 3$ & & $1 * 5$ & & & $3 * 5$ & 40 & Great \\
\hline & $\mathbf{X}$ & & & $3 * 3$ & & $1 * 2$ & & & & $3 * 3$ & & $1 * 5$ & & & $3 * 5$ & 40 & Great \\
\hline \multirow[t]{2}{*}{$\mathbf{X}$} & & \multirow{2}{*}{ Change in topography } & & $3 * 3$ & & $1 * 2$ & & & & $3 * 3$ & & $1 * 5$ & & & $3 * 5$ & 40 & Great \\
\hline & $\mathbf{X}$ & & & $3 * 3$ & & $1 * 2$ & & & & $3 * 3$ & & $1 * 5$ & & & $3 * 5$ & 40 & Great \\
\hline \multirow[t]{2}{*}{$\mathbf{X}$} & & \multirow{2}{*}{ Change in surface water quality } & & $3 * 3$ & & & $2 \div 2$ & & & $3 * 3$ & & $1 * 5$ & & & $3 * 5$ & 42 & Great \\
\hline & $\mathbf{X}$ & & & $3 * 3$ & & $1 * 2$ & & & & $3 * 3$ & & $1 \div 5$ & & & $3 * 5$ & 40 & Great \\
\hline \multirow[t]{2}{*}{$\mathbf{X}$} & & \multirow{2}{*}{ Change in air quality } & & & $2 \div 3$ & $1 * 2$ & & & $2 * 3$ & & & $1 \div 5$ & & $2 * 5$ & & 29 & Small \\
\hline & $\mathbf{X}$ & & & & $2 * 3$ & $1 * 2$ & & & $2 * 3$ & & & $1 * 5$ & & $2 * 5$ & & 29 & Small \\
\hline \multirow[t]{2}{*}{$\mathbf{X}$} & & \multirow{2}{*}{ Loss of habitat } & & $3 * 3$ & & $1 * 2$ & & & & $3 * 3$ & & $1 \div 5$ & & $2 * 5$ & & 35 & Average \\
\hline & $\mathbf{X}$ & & & $3 * 3$ & & $1 * 2$ & & & & $3 * 3$ & & $1 * 5$ & & & $3 * 5$ & 40 & Great \\
\hline \multirow[t]{2}{*}{$\mathbf{X}$} & & \multirow{2}{*}{ Wildlife displacement } & $1 * 3$ & & & $1 * 2$ & & & $2 * 3$ & & & $1 * 5$ & & $2 * 5$ & & 26 & Small \\
\hline & $\mathbf{X}$ & & & $3 * 3$ & & $1 * 2$ & & & & $3 * 3$ & & $1 \div 5$ & & $2 * 5$ & & 35 & Average \\
\hline \multirow[t]{2}{*}{$\mathbf{X}$} & & \multirow{2}{*}{ Creation of new environments } & & $3 * 3$ & & $1 * 2$ & & & & $3 * 3$ & & $1 * 5$ & & & $3 * 5$ & 40 & Great \\
\hline & $\mathbf{X}$ & & & $3 * 3$ & & $1 * 2$ & & & & $3 * 3$ & & $1 * 5$ & & & $3 * 5$ & 40 & Great \\
\hline \multirow[t]{3}{*}{$\mathbf{X}$} & & \multirow{2}{*}{ Loss of vegetation } & $1 * 3$ & & & $1 * 2$ & & & $2 \div 3$ & & & $1 * 5$ & & $2 * 5$ & & 26 & Small \\
\hline & $\mathbf{X}$ & & & $3 * 3$ & & $1 * 2$ & & & & $3 * 3$ & & $1 * 5$ & & & $3 * 5$ & 40 & Great \\
\hline & & & & & & & & throp & pic Er & nviro & nnme & & & & & & \\
\hline $\mathbf{X}$ & & Landscape change (visual impact) & $1 * 3$ & & & $1 * 2$ & & & & $3 * 3$ & & $1 * 5$ & & & $3 * 5$ & 34 & Average \\
\hline & $\mathbf{X}$ & & & $3 * 3$ & & $1 * 2$ & & & & $3 * 3$ & & $1 * 5$ & & & $3 * 5$ & 40 & Great \\
\hline $\mathbf{X}$ & & Limitation of land use & $1 * 3$ & & & & $2 \div 2$ & & $2 \div 3$ & & & $1 * 5$ & & $2 * 5$ & & 28 & Small \\
\hline & $\mathbf{X}$ & Limitation or land use & & $3 * 3$ & & $1 * 2$ & & & & $3 * 3$ & & $1 \div 5$ & & $2 * 5$ & & 25 & Small \\
\hline $\mathbf{X}$ & & Denreciation of land & $1 * 3$ & & & & $2 \div 2$ & & & $3 * 3$ & & $1 * 5$ & & & $3 * 5$ & 33 & Average \\
\hline & $\mathbf{X}$ & Deprectation on lanta & $1 * 3$ & & & & $2 \div 2$ & & & $3 * 3$ & & $1 * 5$ & & & $3 * 5$ & 36 & Average \\
\hline
\end{tabular}

Figure 3. Qualitative matrix of attributes weighting to assess the importance of the environmental impacts of two open-pit coal mining activities

Note. T-temporary; PR-permanent; C-cyclic; L-local; R-regional; ST-short term; MT-medium term; LT-long term; P-positive; N-negative; L-low; A-average; H-high; Degree of importance: 25 to $30=$ small; 31 to $36=$ average; 37 to 42 = great.

Source: Author (2018).

All of the 22 impacts studied have negative direction, 14 of them of high impact. The area in question for a long time mined unsustainably, generating water, non-soil, fauna and flora impacts and also large visual impacts 
(Amaral et al., 2011). Among the evaluated impacts, it was observed that the alteration of the surface water quality was the most important, being assigned the highest value of the range of the class of evaluation of importance proposed (Great importance). Other impacts, such as changes in soil characteristics, creation of new environments and alteration of topography were also classified in the class considered of great importance. Considering the present impacts in the class of small importance, the limitation of the use of the soil and the displacement of the fauna respectively was framed.

\section{Discussion}

The deposition and the incorrect extraction of the coal, reshaped the topography of the degraded site, altering it significantly. In open-pit mining the landscape is remodelled due to the excavation, which aims to the pit opening. In this way, large barren piles arise. According to Nascimento et al. (2002) for every $1000 \mathrm{~kg}$ of mined material, approximately $600 \mathrm{~kg}$ is composed of "tailings and barren" that are deposited in the vicinity of the mined area. In the past, this process was carried out incorrectly, without any soil and vegetation preservation techniques, thus exposing the lower lithological layers and aggregated sulphide minerals (Gonçalves, 2008; Polz, 2008).

These sulphide minerals (marcassite, spharelite, arsenopyrite, chalcopyrite and pyrite- $\mathrm{FeS}_{2}$, the latter recognized as the main pollutant mineral) are responsible for acid drainage, which in turn changes the quality (presence of metals) and increases the turbidity of surface waters in abandoned pits (Figure 2b). There is a lack of information available regarding the maps of the underground areas, however it is assumed that the cracks presented in the galleries are interconnected and that, therefore, they influenced the contamination of other watercourses of the same watershed, being the impact described as regional (Ortiz \& Teixeira, 2002).

Bortoloto et al. (2007) carried out ecotoxicological tests in the Molha River, located in Urussanga-SC, which borders on an open pit coal mine, confirmed that surface water quality was negatively altered. Several studies carried out in other countries corroborate the above, describing that the impacts from mining activities are linked to the degradation of water quality (Herlihy et al., 1990; Maltby \& Booth, 1991; Ghose \& Banerjee, 1995; Winterbourn \& McDiffett, 1996; Ghose \& Majee, 2000; Verb \& Vis, 2000; Cherry et al., 2001; DeNicola \& Stapleton, 2002; Stout \& Papillo, 2004; Freund \& Petty, 2007; Orem, 2007). And also how these impacts are negative and harmful to aquatic life (Lewis, 1973; Scullion \& Edwards, 1980; Winterbourn \& McDiffett, 1996; Garcia-Criado et al., 1999; Kennedy et al., 2003; Pond et al., 2008).

Open pit mines, which after beneficiated generates a large amount of barren, allow the occurrence of particulate matter in the air, which changes its quality (Ghose \& Banerjee, 1995; Ghose \& Majee, 2000; Stout \& Papillo, 2004; Orem, 2007; Hendryx, 2009), occurring more strongly in periods of prolonged drought, low relative humidity or strong winds (Santi et al., 2000). The effects of air pollution by these particles have shown significant changes in the human respiratory system, and may be temporary or permanent (Almeida, 1999). In a study carried out in the vicinity of a mining area in India, Pandey et al. (2014), evaluating air quality, stated that coal mining activities were the most significant when compared to other activities (e.g. emission vehicles and road dust).

In relation to the impact of the opening of the pit, it can be denoted that when the vegetation was suppressed and the excavation was carried out, there was an outcropping of the groundwater. In this way, an artificial lagoon was formed, modifying the terrestrial habitat and permanently preventing the revegetation in that environment. In the area of deposition of the barren, where the vegetation was cut and suppressed, changing the availability of resources to the fauna, consequently the vegetation cover was fragmented. With this, the creation of new environments was observed, where it was observed lands without any vegetal cover or the exclusive presence of herbaceous plants. Several studies carried out in coal mining areas around the world have obtained similar observations (Cornwell, 1971; Fyles et al., 1985; Game et al., 1982; Singh \& Jha, 1987; Jha \& Singh, 1990; Bell et al., 2001; Pandey et al., 2004) this can be explained by the better adaptation of herbaceous species to disturbed sites.

Jica (1997) also argues that, in the areas of extraction and deposit of coal tailings, the reduction of arable land is common, due to the contaminants present in the soil, which increase the potential of contamination also in surrounding regions, which directly contributes to the depreciation of land (CPRM, 2002). With the contamination of the soil, the oxidation of pyrite occurs, resulting in an increase in the acidity and quantity of soluble salts in the soil, these salts are toxic to the plants, being able to inhibit the absorption of water and nutrients by the same. Furthermore, $\mathrm{pH}$ decrease may occur due to the presence of heavy metals (e.g. iron, aluminum, manganese) which also affect plant growth (Carson, 1982; Campos et al., 2010). 
With respect to the anthropic environment, based on the history of the place, it was possible to identify that although there is a great visual impact by both activities, such as the coloration of the water and the mounds of sterile, the pit and the secondary activities coming from the same of major importance, because the impacts caused do not present significant improvements nor the possibility of reversion. Even though the anthropogenic use of these sites is prohibited, these environmental conditions pose a great risk to human health, since there is the release of contaminants by heavy metals that can reach urbanized areas (Rocha-Nicoleite et al., 2017). Studies have shown that soil contamination by mining can lead to serious public problems, such as cancer, with children being the most susceptible (Qu et al., 2012; Man et al., 2010; Zota et al., 2014).

In this way, the study proved the hypothesis that mining activities that were carried out in the study area in the past still continue to cause different types of negative impacts. The activities involved in the processing of coal, such as tailings deposition and pit opening, have been described as having great polluting potential. All 22 environmental impacts evaluated were negative, with $64 \%$ of high impact. The most importance pollution is the one occurring in the biotic environment in the reaction process of pyrite with water and oxygen, causing the acid drainage with the presence of sulphuric acid. According to Silva (2007), in the coal-mining region of Santa Catarina and Rio Grande do Sul, Brazil, water pollution from acid drainage is probably the most significant impact of coal mining and beneficiation activities. Therefore, the impact is complex due to its extent, which by contaminating water resources can extrapolate the limits of the mined area.

The environmental problems of coal mining in the state of Santa Catarina have been forgotten for many years and are not discussed consistently in debates about restoration (Rocha-Nicoleite et al., 2017). As Rocha et al. (2000) found that mining is an economic activity of great relevance, but they do not account for the risks of both environmental and public health (Rocha-Nicoleite et al., 2017). Coal is considered one of the most abundant energy resources in the world (Zhengfu et al., 2010), and it is inevitable that with the use of this and other natural resources, negative environmental effects will occur (Zhengfu et al., 2010), but just as they are of great use, restorative measures should also be considered.

In fact, it was possible to identify that, even after the end of the mining activities, the generation of pollutants is still constant and causes damage to the environment that, if not allied to recovery projects, will continue to occur for decades or even hundreds of years (Alexandre, 1996). Fot that and as a measure for the recovery of the degraded area, a project is recommended to ground the lagoon with acid water, or to remove the contaminants (sulphides) for commercial use. In addition, a project to reallocate tailings and waste deposits according to geotechnical parameters, waterproofed and distant from permanent preservation areas.

Considering that most of the impacts are characterized as permanent, long term, negative direction, degree of high impact and of great importance, it is possible to consider that the mining activities in the locality of Siderópolis deserve special attention in the accomplishment of recovery projects. However, for environmental recovery projects to take place in the mining region effectively, joint support must be obtained from both federal and state efforts, as well as from local companies and the community at large. In conclusion, this work may serve as a subsidy for future studies to evaluate environmental impacts, especially those related to coal mining activities or also related areas, and will serve as a guide for future environmental restoration projects in the Santa Catarina carbouniferous region.

\section{Acknowledgements}

To the Santa Catarina State University, for the technical-financial support. To the FUMDES and CAPES for the assignment of a master and doctorate scholarship.

\section{References}

Alexandre, N. Z. (1996). Influência da mineração de carvão na qualidade das águas superficiais-Revisão Bibliográfica. Revista Tecnologia e Ambiente, 2(1), 53-61.

Almeida, I. T. (1999). A poluição atmosférica por material particulado na mineração a céu aberto (Master's Degree Dissertation, Universidade de São Paulo, São Paulo, Brazil).

Alvares, C. A., Stape, J. L., Sentelhas, P. C., Gonçalves, J. L. M., \& Sparovek, G. (2013). Köppen's climate classification map for Brazil. Meteorologische Zeitschrift, 22(6), 711-728. https://doi.org/10.1127/ 0941-2948/2013/0507

Amaral, J. E., Cancelier, T. S., Krebs, A. S. J., \& Rodrigues, G. T. (2011). Mitigação Ambiental de áreas degradadas pela mineração de carvão em Santa Catarina (3rd ed.). Gramado, RS: CPRM. 
Bailey, T., \& Hooey, C. (2017). From Wasteland to Wonderland": New Uses for Mined Land in Rural Southeast Kansas. The Midwest Quarterly: Pittsburg, 58(3), 252-263.

Bell, F. G., Bullock, S. E. T., Halbich, T. F. J., \& Lindsay, P. (2001). Environmental impacts associated with an abandoned mine in the Witbank Coalfield, South Africa. International Journal of Coal Geology, 45, 195-216. https://doi.org/10.1016/S0166-5162(00)00033-1

Bortolotto, T., Savi, G. D., \& Pich, C. T. (2007). Influência da mineração de carvão na toxicidade das águas superficiais do Rio Molha, Urussanga, SC. Tecnologia e Ambiente, 13.

Brasil. (1980). Decreto $n^{\circ} 85.206$, de 25 de Setembro de 1980. Medidas de prevenção e controle de poluição industrial. Diário Oficial, Brasília, DF.

Brasil. (1986). Resolução CONAMA $n^{\circ} 20$, de 18 de Junho de 1986. Classificação de águas, doces, salobras e salinas do Território Nacional. Diário Oficial, Brasília, DF.

Brasil. (1987). Perfil analítico do carvão (p. 140, 2nd ed.). Porto Alegre: Ministério da Agricultura, Departamento Nacional da Produção Mineral.

Campos, M. L., Almeida, J. A., Silveira, C. B., Gatiboni, L. C., Albuquerque, J. A., Mafra, A. L., ... Santos, J. C. P. (2010). Impactos no solo provocados pela mineração e depósito de rejeitos de carvão mineral. Revista de Ciências Agroveterinárias, 9(2), 198-205.

Cherry, D. S., Currie, R. J., Soucek, D. J., Latimer, H. A., \& Trent, G. C. (2001). An integrative assessment of a watershed impacted by abandoned mined land discharges. Environmental Pollution, 111, 377-388. https://doi.org/10.1016/S0269-7491(00)00093-2

Citadini-Zanette, V. (1999). Diagnóstico ambiental da região carbonífera no sul de Santa Catarina: recuperação de áreas degradadas pela mineração de carvão. Revista Tecnologia e Ambiente, 5, 51-61.

Cornwell, S. M. (1971). Anthracite mining spoils in Pennsylvania. I. Spoil classification and plant cover studies. Journal of Applied Ecology, 8, 401-409. https://doi.org/10.2307/2402879

Costa, T. G., Iwata, B. F., Castros, C. P., Coelho, J. V., Clementino, G. E. S., \& Cunha, L. M. (2016). Impactos ambientais de lixão a céu aberto no Município de Cristalândia, Estado do Piaú, Nordeste do Brasil. Revista Brasileira de Gestão Ambiental e Sustentabilidade, 3(4), 79-86. https://doi.org/10.21438/rbgas.030408

Costanza, R., Cleveland, C., Cooperstein, B., \& Kubiszewski, I. (2011). Can nuclear power be part of the solution? Solutions, 2(3), 29-31. Retrieved from http://www.thesolutionsjournal.com/node/918

CPRM (Serviço Geológico do Brasil). (2002). Relatório Temático do GEO-Brasil (p. 31). Perspectivas do Meio Ambiente para o Brasil: Uso do Subsolo.

Cravotta, C. A. (2008). Dissolved metals and associated constituents in abandoned coal-mine discharges, Pennsylvania, USA. Part 1: Constituent quantities and correlations. Applied Geochemistry, 23(2). 166-202. https://doi.org/10.1016/j.apgeochem.2007.10.011

Cueva, V. P. (2017). Knowledge about mine legacies, international best practice standards and mine closure regulation in the USA and El Salvador (pp. 5-12). An Assessment of Mine Legacies and How to Prevent Them. Springer International Publishing: Cham, Switzerland. https://doi.org/10.1007/978-3-319-53976-8

Daniels, W. L. (1996). Manipulating the chemical properties of soil and mining wastes. In V. H. Alvarez, et al. (Eds.), O solo nos grandes domínios morfoclimáticos do Brasil e o desenvolvimento sustentado (pp. 869-897). Sociedade Brasileira de Ciência do Solo, Universidade Federal de Viçosa.

Denicola, D. M., \& Stapleton, M. G. (2002). Impact of acid mine drainage on benthic communities in streams: The relative roles of substratum vs. aqueous effects. Environmental Pollution, 119, 303-315. https://doi.org/10.1016/S0269-7491(02)00106-9

Fields, S. (2003). The earth's open wounds: Abandoned and orphaned mines. Environ. Health Perspect., 111, A154. https://doi.org/10.1289/ehp.111-a154

Freund, J. G., \& Petty, J. T. (2007). Response of fish and macroinvertebrate bioassessment indices to water chemistry in a mined Appalachian watershed. Environmental Management, 39, 707-720. https://doi.org/ $10.1007 \% 2 \mathrm{Fs} 00267-005-0116-3$

Fugaro, D. A., \& Izidoro, J. C. (2006). Remediação de drenagem ácida de mina usando zeólitas sintetizadas a partir de cinzas leves de carvão. Quim. Nova, 29(4), 735-740. https://doi.org/10.1590/S0100-404220 06000400019 
Fyles, F. W., Fyles, I. H., \& Bell, M. A. M. (1985). Vegetation and soil development on coal mine spoil at high elevation in the Canadian Rockies. Journal of Applied Ecology, 22, 239-248. https://oi.org/10.2307/ 2403341

Game, M. J., Carrel, E., \& Hotrabhavandra, T. (1982). Patch dynamics of plant succession on abandoned surface coal mines: A case history approach. Journal of Applied Ecology, 70, 707-720. https://doi.org/10.2307/ 2260099

Garcia-Criado, F., Tome, A., Vega, F. J., \& Antolin, C. (1999). Performance of some diversity and biotic indices in rivers affected by coal mining in northwestern Spain. Hydrobiologia, 394, 209-217. https://doi.org/10.1023/A:1003634228863

Ghose, M. K., \& Banerjee, S. K. (1995). Status of air pollution caused by coal washery projects in India. Environ Monitor Assess, 38, 97-105. https://doi.org/10.1007/BF00547129

Ghose, M. K., \& Majee, S. R. (2000). Assessment of dust generation due to opencast coal mining-An Indian case study. Environ Monitor Assess, 61, 257-265. https://doi.org/10.1023/A:1006127407401

Gonçalves, L. R. (2008). Avaliação do impacto ambiental na atividade mineradora do carvão e da qualidade da água na bacia hidrográfica do rio Urussanga. Conclusão de curso (Engenharia sanitaria e ambiental). Universidade Federal de Santa Catarina, Florianópolis, Brazil.

Gonçalves, T. M., \& Mendonça, F. A. (2007). Impactos, riscos e vulnerabilidade socioambientais da produção do carvão em Criciúma/SC (Brasil). Revista Raega, 14, 55-65. https://doi.org/10.5380/raega.v14i0.8276

Gutiérrez, M., Mickus, K., \& Camacho, L. M. (2016). Abandoned Pb Zn mining wastes and their mobility as proxy to toxicity: A review. Science Total Environmental, 565, 392-400. https://oi.org/10.1016/ j.scitotenv.2016.04.143

Haase, D., \& Rosenberg, M. (2003). The changing face of the landscape. Research for the Environment, 4, 86-93.

Heikkinen, P. M., Noras, P., \& Salminen, R. (2008). Mine Closure Handbook. Environmental Techniques for the Extractive Industries (p. 169). Geological Society of Finland: Sastamala, Finland.

Hendryx, M. (2009). Mortality from heart, respiratory, and kidney disease in coal mining areas of Appalachia. Int Arch Occup Environ Health, 82, 243-249. https://doi.org/10.1007/s00420-008-0328-y

Herlihy, A. T., Kaufmann, P. R., Mitch, M. E., \& Brown, D. D. (1990). Regional estimates of acid mine drainage impact on streams in the mid-Atlantic and southeastern United States. Water, Air, and Soil Pollution, 50, 91-107. https://doi.org/10.1007/BF00284786

Jha, A. K., \& Singh, J. S. (1990). Revegetation of mine spoils: Review and case study. In B. B. Dhar (Ed.), Environmental Management of Mining Operations (pp. 300-326). Ashish Publishing House, New Delhi.

JICA (Japan International Cooperation Agency). (1997). Interim report for the feasibility study on recuperation of mined-out areas in the South Region of Santa Catarina in the Federative Republico Brazil. Japão.

Johnson, D. B. (2003). Chemical and Microbiological Characteristics of Mineral Spoils and Drainage Waters at Abandoned Coal and Metal Mines. Water, Air and Soil Pollution: Focus, 3(1), 47-66. https://doi.org/ 10.1023/A:1022107520836

Josimovic, B., Petric, J., \& Milijic, S. (2014). The Use of the Leopold Matrix in Carrying Out the EIA for Wind Farms in Serbia. Energy and Environment Research, 4(1), 43. https://doi.org/10.5539/eer.v4n1p43

Keeling, A., \& Sandlos, J. (2017). Ghost towns and zombie mines: The historical dimensions of mine abandonment, reclamation, and redevelopment in the Canadian North. In S. Bocking \& B. Martin, (Eds.), Ice Blink: Navigating Northern Environmental History (pp. 377-420). University of Calgary: Calgary, AB, Canada.

Kennedy, A. J., Cherry, D. S., \& Currie, R. J. (2003). Field and laboratory assessment of a coal processing effluent in the Leading Creek watershed, Meigs County, Ohio. Archives Environmental Contamination and Toxicology, 44, 324-331. https://doi.org/10.1007/s00244-002-2062-X

Kim, S. M., Suh, J., Oh, S., Son, J., Hyun, C. U., Park, H. D., ... Choi, Y. (2016). Assessing and prioritizing environmental hazards associated with abandoned mines in Gangwon-do, South Korea: The Total Mine Hazards Index. Environmental Earth Science, 75, 1-14. https://doi.org/10.1007/s12665-016-5283-4 
Kubit, O. E., Pluhar, C. J., \& De Graff, J. V. (2015). A model for prioritizing sites and reclamation methods at abandoned mines. Environ. Earth Sci., 73, 7915-7931. https://doi.org/10.1007\%2Fs12665-014-3949-3

Larondelle, N., \& Haase, D. (2012). Valuing post-mining landscapes using an ecosystem services approach-An example from Germany. Ecological Indicators, 18, 567-574. https://doi.org/10.1016/j.ecolind.2012.01.008

Leopold, L. B., Clarke, F. E., Hanshaw, B. B., \& Baisley, J. R. (1971). A procedure for Evaluating Environmental Impact. Washington: U. S. Geological Survey.

Lewis, K. (1973). The effect of suspended coal particles on the life forms of the aquatic moss Eurynchium riparioides (Hedw.) I. The gametophyte plant. Freshwater Biology, 3, 251-257. https://doi.org/10.1111/ j.1365-2427.1973.tb00920.x

Li, Z., Ma, Z., Kuijp, T. J. V., Yuan, Z., \& Huang, L. (2014). A review of soil heavy metal pollution from mines in China: Pollution and health risk assessment. Science of the Total Environment, 468-469(15), 843-853. https://doi.org/10.1016/j.scitotenv.2013.08.090

Lima, A. T., Mitchell, K., O’Connell, D. W., Verhoeven, J., \& Van Cappellen, P. (2016). The legacy of surface mining: Remediation, restoration, reclamation and rehabilitation. Environ. Sci. Policy, 66, $227-233$. https://doi.org/10.1016/j.envsci.2016.07.011

Limpitlaw, D., \& Briel, A. (2014). Post-mining land use opportunities in developing countries-A review. J. S. Afr. Inst. Min. Metall., 114, 899-903.

Macêdo, A. J. B., Bazante, A. J., \& Bonates, E. J. L. (2001). Seleção do Método de Lavra: Arte e Ciência. Revista Escola de Minas, 54(3). https://doi.org/10.1590/S0370-44672001000300010

Maltby, L., \& Booth, R. (1991). The effect of coal-mine effluent on fungal assemblage and leaf breakdown. Water Research, 25, 247-250. https://doi.org/10.1016/0043-1354(91)90003-9

Man, Y. B., Sun, X. L., Zhao, Y. G., Lopez, B. N., Chung, S. S., \& Wu, S. C. (2010). Health risk assessment of abandoned agricultural soils based on heavy metal contents in Hong Kong, the world's most populated city. Environ Int., 36, 570-6. https://doi.org/10.1016/j.envint.2010.04.014

Mborah, C., Bansah, K. J., \& Boateng, M. K. (2015). Evaluating alternate post-mining land-uses: A review. Env. Poll., 5, 14. https://doi.org/10.5539/ep.v5n1p14

McHaina, D. M. (2001). Environmental planning considerations for the decommissioning, closure and reclamation of a mine site. Int. J. Surf. Min. Reclamat. Environ., 15, 163-176. https://doi.org/10.1076/ ijsm.15.3.163.3412

Merem, E. C., Twamasi, Y., Wesley, J., Isokpehi, P., Shenge, M., Fageir, S., .. Nwagboso, E. (2017). Assessing the Ecological Effects of Mining in West Africa: The Case of Nigeria. International Journal of Mining Engineering and Mineral Processing, 6(1), 1-19. https://doi.org/10.5923/j.mining.20170601.01

Milioli, G. (2005). Mining, environment, and development in Southern Santa Catarina, Brazil: non-governmental organization, Terra Verde and its ideas for sustainsbility. J. Environ. Sci., 33, 23-38.

Mishra, S. K., Hitzhusen, F. J., Sohngen, B. L., \& Guldman, J. M. (2012). Costs of abandoned coal mine reclamation and associated recreation benefits in Ohio. Journal of Environmental Management, 100(15), 52-58. https://doi.org/10.1016/j.jenvman.2012.01.021

Morris, P., \& Therivel, R. (1995). Methods of Environmental Impact Assessment: The natural and built Environmental Series 2 (2nd ed.). Londres: UCL Press Limited.

Nascimento, F. M. F., Mendonça, R. M. G., Macêdo, M. I. F., \& Soares, P. S. M. (2002). Impactos ambientais nos recursos hídricos da exploração de carvão em santa Catarina. Congresso brasileiro de mina a céu aberto, 1; Congresso brasileiro de mina subterrânea, 2. Belo Horizonte.

Orem, W. H. (2007). Coal slurry: Geochemistry and impacts on human health and environmental quality. Retrieved from http://www.sludgesafety.org/misc/wm_orem_powerpoint/index.html

Ortiz, L., \& Teixeira, E. C. (2002). Influência das atividades de processamento do carvão sobre a qualidade dos recursos hídricos superficiais. In E. C. Teixeira, \& M. J. R. P. Pires (Eds.), Meio ambiente e carvão: Impactos da utilização e exploração (pp. 301-340). Cadernos de Planejamento e Gestão Ambiental (No. 2). Porto Alegre: Fepam. 
Pandey, B., Agrawal, M., \& Singh, S. (2014). Assessment of air pollution around coal mining area: Emphasizing on spatial distributions, seasonal variations and heavy metals, using cluster and principal component analysis. Atmospheric Pollution Research, 5, 79-86. https://doi.org/10.5094/APR.2014.010

Pepper, M., Roche, C. P., \& Mudd, G. M. (2014). Mining legacies-Understanding life-of-mine across time and space. Proceedings of the Life-of-Mine Conference 2014 (Vol. 16-18, pp. 1449-1466). Brisbane, Australia.

Polz, J. A. (2008). Recuperação de Áreas Degradadas pela Mineração a Céu Aberto em Santa Catarina: Gestão de Rejeitos e Revegetação. Carvão Brasileiro: Tecnologia e Meio Ambiente (pp. 75-94). Rio de Janeiro, CETEM/MCT.

Pompêo, M. L. M., Moschini-Carlos, V., Alexandre, N. Z., \& Santos, E. (2004). Qualidade da água em região alterada pela mineração de carvão na microbacia do rio Fiorita (Siderópolis, Estado de Santa Catarina). Acta Scientiarum. Biological Sciences, 26(2), 125-136. https://doi.org/10.4025/actascibiolsci.v26i2.1610

Pond, G. J., Passmore, M. E., Borsuk, F. A., Reynolds, L., \& Rose, C. J. (2008). Downstream effects of mountaintop coal mining: comparing biological conditions using family- and genus-level macroinvertebrate bioassessment tools. J. N. Am. Benthol. Soc., 27(3), 717-737. https://doi.org/10.1899/08-015.1

Qu, C. S., Sun, K., Wang, S. R., Huang, L., \& Bi, J. (2012). Monte Carlo simulation based health risk assessment of heavy metal pollution: A case study in Qixia mining area, China. Hum Ecol Risk Assess, 18, 733-50. https://doi.org/10.1080/10807039.2012.688697

Rocha-Nicoleite, E. (2015). Processos iniciais de restauração ecológica em areas degradadas por mineração de carvão (Doctor Thesis, Universidade federal do Rio Grande do Sul, Porto Alegre).

Rocha-Nicoleite, E., Campos, M. L., \& Citadini-Zanette, V. (2013). Mata Ciliar: Implicações técnicas sobre a restauração após mineração de carvão. SATC, Criciúma.

Rocha-Nicoleite, E., Overbeck, G. E., \& Muller, S. C. (2017). Degradation by coal mining should be priority in restoration planning. Perspectives in Ecology and Conservation, 15(3), 202-205. https://doi.org/10.1016/ j.pecon.2017.05.006

Sánchez, L. E. (2012). Avaliação de impacto ambiental: Conceitos e métodos (2nd ed). São Paulo, SP: Oficina de Textos.

Sánchez, L. E. (2013). Avaliação de impacto ambiental: Conceitos e métodos (2nd ed.). São Paulo: Oficina de Textos.

Santi, A. M. M., Suzuki, R. Y., \& Oliveira, R. G. de. (2000). Monitoramento da qualidade do ar no município de Itabira, MG: avaliação dos resultados em anos recentes (1997/99) e das perspectivas de modernização da rede de monitoramento no contexto do licenciamento ambiental corretivo da CVRD (pp. 1-12). XXVII Congresso Interamericano de Ingenieria Sanitaria y Ambiental, 2000, Porto Alegre, Congresso Interamericano de Ingenieria Sanitaria y Ambiental.

Santos, R. F. (2004). Planejamento ambiental: Teoria e prática. São Paulo, SP: Oficina de Textos.

Sarma, K. (2005). Impact of Coal Mining on Vegetation: A Case Study in Jaintia Hills District of Meghalaya, India (Master's Degree Dissertation, International Institute for Geo-information Science and Earth Observation, India).

Schmidt, H., \& Glaesser, C. (1998). Multitemporal analysis of satellite data and their use in the monitoring of the environmental impacts of open cast lignite mining areas in Eastern Germany. Int. J. Rem. Sens., 19, 245-2260. https://doi.org/10.1080/014311698214695

Scullion, J., \& Edwards, R. W. (1980). The effects of coal industry pollutants on the macroinvertebrate fauna of a small river in the South Wales coalfield. Freshwater Biology, 10, 141-162. https://doi.org/10.1111/ j.1365-2427.1980.tb01189.x

Sheoran, V., Sheoran, A. S., \& Poonia, P. (2010). Soil reclamation of abandoned mine land by revegetation: A review. Int. J. Soil Sediment Water, 3(2), 13.

Silva, J. P. S. (2007). Impactos ambientais causados por mineração. Revista Espaço da Sophia, 8(1).

Singh, J. S., \& Jha, A. K. (1987). Ecological aspects of reclamation and revegetation of coal mine spoils. In D. D. Dhar (Ed.), Proceedings of National Workshop on Environmental Management of Mining Operations in India-A status paper (pp. 73-86). Department of Mining Engineering, B.H.U., Vanarasi, India. 
Slonecker, E. T., \& Benger, M. J. (2001). Remote sensing and mountaintop mining. Remote Sensing Reviews, 20(4), 293-322. https://doi.org/10.1080/02757250109532440

Soares, E. R., Mello, J. W. V., Corrêa, M. L. T., Schaefer, C. E. G. R., \& Costa, L. M. (2006). Cinza e carbonato de cálcio na mitigação de drenagem ácida em estéril de mineração de carvão. Revista Brasileira de Ciência do Solo, 30, 171-181. https://doi.org/10.1590/S0100-06832006000100017.

Sobral, I. S., Santana, R. K. O., Gomes, L. J., Ribeiro, G. T., Santo, J. R., \& Costa, M. (2007). Avaliação dos impactos ambientais no Parque Nacional Serra de Itabaiana-SE. Revista Caminhos de Geografia, 8(24), 102-110.

Spiazzi, F. R., Miquelluti, D., Campos, M. L., \& Hugen, C. (2009). Estudo comparativo do uso e ocupação do solo em diferentes épocas em uma área de mineração em Lauro Muller (pp. 229-230). XXXII Congresso Brasileiro de Ciência do Solo, Fortaleza, 2009; Anais do XXXII Congresso Brasileiro de Ciência do Solo. Fortaleza: SPH Comunicação Visual.

Stout, B. M., \& Papillo, J. (2004). Well water quality in the vicinity of a coal slurry impoundment near Williamson, West Virginia. Wheeling Jesuit University, Wheeling.

Venkateswarlu, K., Nirola, R., Kuppusamy, S., Thavamani, P., Naidu, R., \& Megharaj, M. (2016). Abandoned metalliferous mines: Ecological impacts and potential approaches for reclamation. Rev. Environ. Sci. Bio/Technol., 15, 327-354. https://doi.org/10.1007\%2Fs11157-016-9398-6

Verb, R. G., \& Vis, M. L. (2000). Comparison of benthic diatom assemblages from streams draining abandoned and reclaimed coal mines and nonimpacted sites. Journal of the North American Benthological Society, 19, 274-288. https://doi.org/10.2307/1468070

Winterbourn, M. J., \& Mcdiffett, W. F. (1996). Benthic faunas of streams of low pH but contrasting water chemistry in New Zealand. Hydrobiologia, 341(2), 101-111. https://doi.org/10.1007/BF00018114

World Coal Association. (2011). Coal Facts 2011. World Coal Association. Retrieved from http://www.worldcoal.org/resources/coal-statistics

Yenilmez, F., Kuter, N., Emil, M. K., \& Aksoy, A. (2011). Evaluation of pollution levels at an abandoned coal mine site in Turkey with the aid of GIS. International Journal of Coal Geology, 86(1), 12-19. https://doi.org/10.1016/j.coal.2010.11.012

Zhengfu, B., Inyang, G., Daniels, J., Otto, F., \& Struthers, S. (2010). Environmental issues from coal mining and their solutions. Mining Science and Technology, 20, 215-0223. https://doi.org/10.1016/S1674-5264 (09)60187-3

Zipper, C. E., Burger, J. A., Skousen, J. G., Angel, P. N., Barton, C. D., Davis, V., \& Franklin, J. A. (2011). Restoring Forests and Associated Ecosystem Services on Appalachian Coal Surface Mines. Environmental Management, 47(5), 751-765. https://doi.org/10.1007/s00267-011-9670-z

Zota, A. R., Schaider, L. A., Ettinger, A. S., Wright, R. O., Shine, J. P., \& Spengler, J. D. (2011). Metal sources and exposures in the homes of young children living near a mining-impacted Superfund site. $J$ Expo Sci Environ Epidemiol, 21, 495-505. https://doi.org/10.1038/jes.2011.21

\section{Copyrights}

Copyright for this article is retained by the author (s), with first publication rights granted to the journal.

This is an open-access article distributed under the terms and conditions of the Creative Commons Attribution license (http://creativecommons.org/licenses/by/4.0/). 